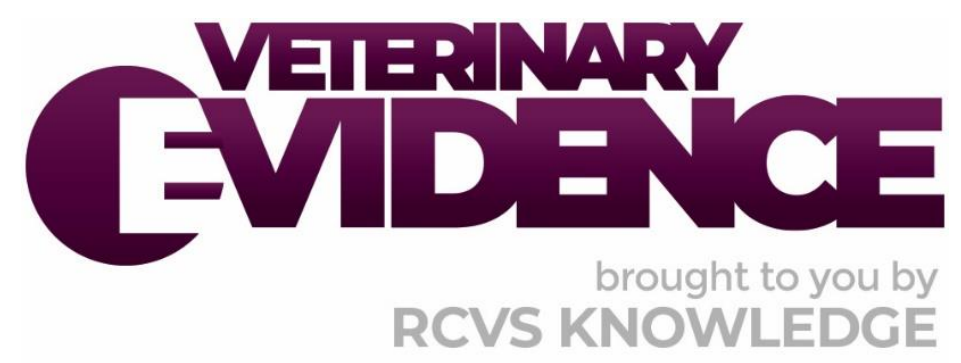

\title{
Current evidence supporting simultaneous prophylactic gastropexy in canine patients undergoing complete splenectomy
}

\author{
A Knowledge Summary by
}

Olivia Harris $\mathrm{BS}^{1^{*}}$

Wanda J Gordon-Evans DVM PhD DACVS DACVSMR ${ }^{1}$

\footnotetext{
1 University of Minnesota College of Veterinary Medicine, 1365 Gortner Ave, St Paul, MN 55108, USA

* Corresponding Author (olivia.harris@westvet.net)
}

ISSN: 2396-9776

Published: 24 Dec 2021

in: The Veterinary Evidence journal Vol 6, Issue 4

DOI: https://doi.org/10.18849/ve.v6i4.443

Reviewed by: Zofia Lisowski (PhD FHEA BVSc) and April L Paul (DVM DACVECC) 


\section{KNOWLEDGE SUMMARY}

\section{PICO question}

In dogs that have undergone a complete splenectomy, does performing a concurrent gastropexy decrease the risk of future gastric dilatation-volvulus (GDV) development when compared to not performing a concurrent gastropexy?

\section{Clinical bottom line}

\section{Category of research question}

\section{Risk}

\section{The number and type of study designs reviewed}

Five papers were critically reviewed which included one retrospective case series, one retrospective casecontrol study, and three combined retrospective cohort and cross-sectional survey studies

\section{Strength of evidence}

Weak

\section{Outcomes reported}

In dogs that have had a complete splenectomy, there is no conclusive evidence that prophylactic gastropexy decreases the risk of lifetime GDV development

\section{Conclusion}

Based on the limited information available, it is difficult to conclude if prophylactic gastropexy should be recommended routinely at the time of complete splenectomy

\section{How to apply this evidence in practice}

The application of evidence into practice should take into account multiple factors, not limited to: individual clinical expertise, patient's circumstances and owners' values, country, location or clinic where you work, the individual case in front of you, the availability of therapies and resources.

Knowledge Summaries are a resource to help reinforce or inform decision making. They do not override the responsibility or judgement of the practitioner to do what is best for the animal in their care.

\section{The evidence}

The evidence available consists of all retrospective studies. Retrospective studies are low on the hierarchy of evidence due to the difficulty in avoiding sources of bias and confounding. Inconsistent findings were found between the critically reviewed studies and could be due to a variety of reasons including study design, disease processes that led to complete splenectomy, inclusion and exclusion criteria, and inconsistent followup times, among other reasons. Based on the weak level of evidence and inconsistent findings, it is difficult to make a conclusion regarding the benefit of performing concurrent gastropexy in dogs receiving splenectomy. 


\begin{tabular}{|c|c|}
\hline \\
\hline \multicolumn{2}{|l|}{$\begin{array}{l}\text { DeGroot et al. (2016) } \\
\text { Population: }\end{array}$} \\
\hline \multirow{2}{*}{$\begin{aligned} \text { Sample size: } \\
\text { Intervention details: }\end{aligned}$} & \multirow[b]{2}{*}{$\begin{array}{l}\text { - Medical records of dogs were reviewed for patient history } \\
\text { and follow-up information. } \\
\text { - In } 101 \text { dogs a complete splenectomy was performed. The } \\
\text { surgical technique was recorded for } 93 \text { dogs which included } \\
\text { suture ligation }(n=36) \text {, suture ligation in combination with a } \\
\text { ligate-divide-staple device }(n=28) \text {, suture ligation in } \\
\text { combination with a vessel-sealing device }(n=15) \text {, or use of a } \\
\text { vessel-sealing device alone }(n=14) \text {. } \\
\text { - In one dog the splenic pedicle was derotated and the spleen } \\
\text { was repositioned and left in situ. }\end{array}$} \\
\hline & \\
\hline Study design: & \\
\hline Outcome studied: & $\begin{array}{l}\text { Retrospective multi-centre case series. } \\
\text { - The percentage of dogs surviving to hospital discharge. } \\
\text { - The proportion of dogs undergoing splenectomy for PST that } \\
\text { develop GDV in later life. }\end{array}$ \\
\hline $\begin{array}{l}\text { Main findings: } \\
\text { (relevant to PICO question): }\end{array}$ & $\begin{array}{l}\text { - Of the } 64 \text { dogs that follow-up information was available, } 49 \\
\text { ( } 77 \% \text { ) had a concurrent gastropexy at the time of } \\
\text { splenectomy. } \\
\text { - In the dogs that had a concurrent gastropexy ( } 49 \text { dogs), one } \\
\text { dog ( } 2 \% \text { ) developed GDV } 3 \text { years after surgery. } \\
\text { - In the dogs that did not have a concurrent gastropexy ( } 15 \\
\text { dogs), one dog ( } 2 \% \text { ) developed GDV } 4 \text { months after surgery. } \\
\text { - The percentages of dogs with and without gastropexy that } \\
\text { developed GDV were not significantly different. } \\
\text { - The authors could not draw meaningful conclusions } \\
\text { regarding the importance of gastropexy or the risk of GDV in } \\
\text { dogs following splenectomy for PST. }\end{array}$ \\
\hline Limitations: & $\begin{array}{l}\text { - Retrospective nature of this study. } \\
\text { - Only cases of PST were included. } \\
\text { - Uniform follow-up information was not available for all dogs. } \\
\text { - Underpowered study due to small sample size. }\end{array}$ \\
\hline
\end{tabular}

Goldhammer et al. (2010)

Population: Retrospective Study \#1:

- Dogs that had undergone splenectomy were compared with records of dogs that had undergone other abdominal surgery at a referral hospital between 1999 and 2007.

Retrospective Study \#2:

- Dogs that had presented for a non-elective gastropexy at a referral hospital between 1999 and 2007. 


\begin{tabular}{|c|c|}
\hline & $\begin{array}{l}\text { - No dogs in either the non-elective gastropexy group or the } \\
\text { control group had a history of previous splenectomy. }\end{array}$ \\
\hline Sample size: & $\begin{array}{l}\text { Retrospective Study \#1: } \\
\text { - } 37 \text { case group dogs presenting for splenectomy compared to } \\
43 \text { bodyweight matched control group dogs presenting for } \\
\text { other abdominal surgery. } \\
\text { Retrospective Study \#2: } \\
\text { - } 33 \text { case group dogs presenting for non-elective gastropexy } \\
\text { due to recent or current GDV compared to } 39 \text { bodyweight } \\
\text { matched control group dogs presenting for unrelated } \\
\text { reasons. }\end{array}$ \\
\hline Intervention details: & $\begin{array}{l}\text { Retrospective Study \#1: } \\
\text { - Medical records of dogs which had splenectomy performed } \\
\text { at a veterinary referral hospital were reviewed. } \\
\text { The incidence of GDV in the } 12 \text { months following } \\
\text { splenectomy was established by follow-up survey of } \\
\text { referring veterinary surgeons. } \\
\text { - The results were compared to a control group of dogs } \\
\text { presenting for abdominal surgeries that did not include } \\
\text { splenectomy. } \\
\text { Retrospective Study \#2: } \\
\text { - Medical records of dogs which presented for non-elective } \\
\text { gastropexy at a veterinary referral hospital were reviewed. } \\
\text { - The occurrence of previous splenectomy in dogs that } \\
\text { presented with GDV was compared to that of a control } \\
\text { group. }\end{array}$ \\
\hline Study design: & Retrospective single-centre cohort study and cross-sectional survey. \\
\hline Outcome studied: & $\begin{array}{l}\text { Retrospective Study \#1: } \\
\text { - The prevalence of GDV in dogs with splenectomy compared } \\
\text { to other abdominal surgeries. } \\
\text { Retrospective Study \#2: } \\
\text { - The prevalence of splenectomy performed in the past in } \\
\text { dogs presenting with GDV. }\end{array}$ \\
\hline $\begin{array}{l}\text { Main findings: } \\
\text { (relevant to PICO question): }\end{array}$ & $\begin{array}{l}\text { Retrospective Study \#1: } \\
\text { - In the case group, } 1 / 37 \text { dogs ( } 3 \% \text { ) developed GDV } 48 \text { hours } \\
\text { following splenectomy. No other dogs in the case group } \\
\text { developed GDV within the } 12 \text { month follow-up period. } \\
\text { - No dogs in the control group developed GDV within the } 12 \\
\text { month follow-up period. } \\
\text { - There was no evidence that splenectomy was associated } \\
\text { with an increased incidence of subsequent GDV. } \\
\text { Retrospective Study \#2: } \\
\text { - No association between a current episode of GDV and } \\
\text { previous splenectomy was found. }\end{array}$ \\
\hline Limitations: & $\begin{array}{l}\text { - Retrospective nature of this study. } \\
\text { - Study included patients from only one veterinary referral } \\
\text { hospital. } \\
\text { - Follow-up time of } 12 \text { months may have falsely lowered true } \\
\text { incidence of GDV development. }\end{array}$ \\
\hline
\end{tabular}


- Retrospective questionnaire may have resulted in inaccurate data.

- Underpowered study due to small sample size.

\begin{tabular}{|c|c|}
\hline \multicolumn{2}{|l|}{ Grange et al. (2012) } \\
\hline Population: & $\begin{array}{l}\text { Dogs that underwent splenectomy between January } 2002 \text { and } \\
\text { February } 2010 \text { at Angell Animal Medical Center. }\end{array}$ \\
\hline Sample size: & $\begin{array}{l}172 \text { Dogs that underwent splenectomy were compared to } 47 \text { sex- } \\
\text { matched dogs that underwent enterotomy. }\end{array}$ \\
\hline Intervention details: & $\begin{array}{l}\text { - Medical records were reviewed for patient information. } \\
\text { - Follow-up information was obtained via medical records } \\
\text { review and a written client questionnaire. }\end{array}$ \\
\hline Study design: & Retrospective single-centre cohort study and cross-sectional survey. \\
\hline Outcome studied: & $\begin{array}{l}\text { Whether dogs undergoing splenectomy had an increased risk of } \\
\text { GDV, especially in breeds considered to be at high risk for GDV, } \\
\text { compared with a control group of dogs undergoing enterotomy. }\end{array}$ \\
\hline $\begin{array}{l}\text { Main findings: } \\
\text { (relevant to PICO question): }\end{array}$ & $\begin{array}{l}\text { GDV developed after surgery in } 14 / 172 \text { dogs ( } 8.1 \% \text { ) in the } \\
\text { splenectomy group and in } 3 / 47 \text { dogs }(6.4 \% \text { ) in the control } \\
\text { (enterotomy) group with a median follow-up time of } 65.5 \\
\text { and 1,577 days for medical records and owner } \\
\text { questionnaires in the splenectomy group respectively, and } \\
14 \text { and } 740 \text { days for medical records and owner } \\
\text { questionnaires in the control (enterotomy) group } \\
\text { respectively. } \\
\text { There was no significant difference in incidence of GDV } \\
\text { between the splenectomy and control groups. }\end{array}$ \\
\hline Limitations: & $\begin{array}{l}\text { - Retrospective nature of this study. } \\
\text { - Study included patients from only one veterinary referral } \\
\text { hospital. } \\
\text { - Dogs in the splenectomy group were significantly older and } \\
\text { heavier than in the control group. } \\
\text { - All dogs that underwent splenectomy for splenic torsion } \\
\text { received a prophylactic gastropexy and were excluded from } \\
\text { the study results. } \\
\text { - Retrospective questionnaire may have resulted in inaccurate } \\
\text { data. }\end{array}$ \\
\hline
\end{tabular}

Maki et al. (2017)

\begin{tabular}{|r|l|}
\hline Population: & $\begin{array}{l}\text { Medium- to large-breed dogs that had undergone surgery with a } \\
\text { vessel sealing or a stapling device at Ocean State Veterinary } \\
\text { Specialists from 2008 to 2015. }\end{array}$ \\
\hline Sample size: & $\begin{array}{l}\text { 238 dogs that underwent splenectomy and 209 dogs that underwent } \\
\text { emergency laparotomy. Dogs that had a gastropexy at any point } \\
\text { prior to or during the study were excluded. }\end{array}$ \\
\hline Intervention details: & $\begin{array}{l}\text { - Medical records were reviewed for patient history. } \\
\text { - Case follow-up was completed by reviewing medical records }\end{array}$ \\
\hline
\end{tabular}




\begin{tabular}{|c|c|}
\hline & $\begin{array}{l}\text { and conducting either an email or telephone interview with } \\
\text { the owner and/or the primary care veterinarian. }\end{array}$ \\
\hline Study design: & Retrospective single-centre cohort study and cross-sectional survey. \\
\hline Outcome studied: & $\begin{array}{l}\text { - To determine the rate of occurrence of GDV following } \\
\text { splenectomy in medium- to large-breed dogs. } \\
\text { - To define the time from surgery to occurrence of GDV in } \\
\text { affected dogs. } \\
\text { - To determine if there was an association of age, weight, sex, } \\
\text { or presence of a haemoabdomen at time of surgery with } \\
\text { occurrence of GDV. }\end{array}$ \\
\hline $\begin{array}{l}\text { Main findings: } \\
\text { (relevant to PICO question): }\end{array}$ & $\begin{array}{l}\text { - } 10 / 238 \text { dogs ( } 4 \% \text { ) in the splenectomy group and } 3 / 209 \text { dogs } \\
(1 \% \text { ) in the control group were considered to have had a } \\
\text { GDV following surgery. } \\
\text { - There was no significant difference in incidence of GDV } \\
\text { between the case and control groups. } \\
\text { Median time from surgery to subsequent GDV was } 124 \text { days } \\
\text { (range } 15-1,273 \text { days) in the splenectomy group and } 1029 \\
\text { days (range } 570-1,663 \text { days) in the control group. This } \\
\text { difference was significant. }\end{array}$ \\
\hline Limitations: & $\begin{array}{l}\text { - Retrospective nature of this study. } \\
\text { - Dogs were excluded from the study if the spleen was not } \\
\text { submitted for histopathology, which could have lowered } \\
\text { incidence of GDV. } \\
\text { - Dogs were excluded from the study if the primary surgical } \\
\text { technique utilised was suture ligation, but, the authors did } \\
\text { not note how many dogs, if any, were actually excluded } \\
\text { from the study due to this technique. } \\
\text { - This study included dogs that died of suspected GDV but not } \\
\text { confirmed. } \\
\text { - Dogs in the splenectomy group were significantly older at } \\
\text { the time of surgery. } \\
\text { Retrospective follow-up with owners and primary care } \\
\text { veterinarians may have resulted in inaccurate data with } \\
\text { median follow-up in the splenectomy group being } 471 \text { days } \\
\text { (range } 19-1,688 \text { days) and in the control group being } 1,184 \\
\text { days (range } 214-2,776 \text { days). }\end{array}$ \\
\hline
\end{tabular}

Sartor et al. (2013)

Population: Dogs that underwent exploratory laparotomy or abdominal ultrasonography at either the Matthew J. Ryan Veterinary Hospital of the University of Pennsylvania from August 2004 to August 2009 or the Veterinary Medical and Surgical Group in Ventura, California from January 2006 to August 2009.

Sample size: 151 dogs treated surgically for GDV and 302 control dogs with no history of GDV. Controls were matched within 3 years of age and 5 $\mathrm{kg}$ to case dogs and related as closely as possible in regard to sex, neuter status, and breed. 


\begin{tabular}{|c|c|}
\hline Intervention details: & $\begin{array}{l}\text { Medical records were searched for dogs that underwent exploratory } \\
\text { laparotomy or abdominal ultrasonography. }\end{array}$ \\
\hline Study design: & Retrospective multi-centre case-control study \\
\hline Outcome studied: & $\begin{array}{l}\text { Determine whether there is a significant association } \\
\text { between previous splenectomy and the development of } \\
\text { GDV. } \\
\text { For patients without a spleen, the time elapsed between } \\
\text { splenectomy and the development of GDV was recorded for } \\
\text { the case animals, and the time elapsed between } \\
\text { splenectomy and either laparotomy or abdominal } \\
\text { ultrasonography was recorded for the control animals. }\end{array}$ \\
\hline $\begin{array}{l}\text { Main findings: } \\
\text { (relevant to PICO question): }\end{array}$ & $\begin{array}{l}\text { - } 6 / 151 \text { dogs ( } 4 \% \text { ) in the GDV group and } 3 / 302 \text { dogs ( } 1 \% \text { ) in } \\
\text { the control group had a history of previous splenectomy. } \\
\text { - In the case group (dogs with GDV development), the odds of } \\
\text { having a history of previous splenectomy was } 5.3 \text { times } \\
\text { those of dogs without a history of previous splenectomy. } \\
\text { - Time elapsed between splenectomy and GDV ranged from } \\
1.5 \text { to } 12 \text { months, with a median time of } 2.5 \text { months. }\end{array}$ \\
\hline Limitations: & $\begin{array}{l}\text { - Retrospective nature of this study. } \\
\text { - Aetiology of splenectomy was only discussed for dogs that } \\
\text { eventually developed GDV. } \\
\text { Did not discuss if previous gastropexy was performed in any } \\
\text { patients. } \\
\text { Wide confidence interval ( } 95 \% \mathrm{Cl}, 1.1 \text { to } 26.8 \text { ) for the odds } \\
\text { of dogs with GDV (case group) having a previous } \\
\text { splenectomy compared to not having a previous } \\
\text { splenectomy. }\end{array}$ \\
\hline
\end{tabular}

\section{Appraisal, application and reflection}

Gastric dilatation-volvulus (GDV) is a life-threatening condition in which the stomach dilates and rotates on its mesenteric axis. While this disease process is more commonly recognised in large- to giant-breed dogs, a study performed by Maki et al. (2017) revealed that GDV development is a documented post-surgical complication in some patients that have undergone a splenectomy.

It has been suggested in the veterinary literature that a prophylactic gastropexy should be considered in dogs that have undergone complete splenectomy to decrease the lifetime risk of GDV development, but the basis for this recommendation has been anecdotal. While there may be a perceived benefit to performing a gastropexy in any large- or giant-breed dogs undergoing a splenectomy, the current literature does not provide a true consensus. It may be that breeds predisposed to splenic torsion are also predisposed to development of GDV instead of a causative relationship between complete splenectomy and GDV development. Grange et al. (2012) discussed that a gastropexy is a relatively routine procedure that may help prevent GDV development, which is a life-threatening and quickly progressive disease, but could not find causation to perform a gastropexy in patients undergoing a previous complete splenectomy. Goldhammer et al. (2010) evaluated 33 dogs presenting for a non-elective gastropexy procedure due to GDV and noted that no study patients had a history of a previous splenectomy being performed. DeGroot et al. (2016) also found no statistical significance between GDV development in post-splenectomy patients (1/49 dogs) compared to patients that had not undergone a previous splenectomy ( $1 / 15$ dogs). Hypotheses as to why there anecdotally may be an increased risk of GDV development secondary to complete splenectomy include increased laxity of gastric ligaments secondary to transection and increased intra-abdominal dead space, both of which allow for increased gastric mobility in the abdominal cavity. 
DeGroot et al. (2016), a retrospective case series, could not draw meaningful conclusions regarding the importance of prophylactic gastropexy after complete splenectomy secondary to PST as there was no significant difference in the percentage of dogs with and without gastropexy that developed GDV. Goldhammer et al. (2010), Grange et al. (2012), and Maki et al. (2017), all of which were retrospective cohort studies with a cross-sectional survey component, drew similar conclusions to DeGroot et al. (2016) in that it was difficult to draw clinical conclusions based on results of their respective studies and further research was needed. Sartor et al. (2013), a retrospective case-control study, found results that conflicted with the previously mentioned studies. To the author's knowledge, this is the only study truly documenting an increased odds of previous splenectomy having been performed in GDV patients, but it is difficult to draw meaningful clinical conclusions regarding the PICO question from these results as cases were compared to a general population of dogs that were presented to the veterinary hospital for a wide variety of ailments. In Sartor et al. (2013), they found that the odds of GDV in dogs with a history of previous splenectomy were significantly increased compared to those of dogs without a history of previous splenectomy, but the authors did not discuss whether any cases or controls had a gastropexy procedure previously and also did not discuss the aetiology of why a complete splenectomy was performed in the patients.

Grange et al. (2012) made an important point that while performing a prophylactic gastropexy is a relatively routine procedure, it is crucial to remember that the procedure is not without risk. Possible complications of prophylactic gastropexy, while rare, include anaesthetic complications, surgical failure with need for possible repair, changes in gastric motility, leakage of caustic stomach contents into the abdominal cavity secondary to full-thickness tissue penetration, and other complications related to increased surgery and anaesthesia time. It is essential to take into consideration individual patient factors when deciding if the benefit of an extra surgical procedure outweighs the risks. The documented complication rates for a gastropexy depends on the specific technique utilised with a recent shift towards a more minimally invasive procedure. Loy Son et al. (2016) evaluated complications following laparoscopic-assisted gastropexy in dogs. This study noted an intraoperative complication rate of $4-10 \%$ which included organ laceration, unsatisfactory suture location, and surgical access issues. A postoperative complication rate of $34 \%$ was found secondary to surgical site abnormalities (swelling, bruising, erythema, seroma formation, surgical site infection) with a majority of complications being minor and self-limiting.

Further research is needed in order to answer this PICO question. More ideal study designs include prospective cohort or case-control studies with follow-up information taken over the course of each dog's lifetime, but ethical dilemmas may preclude these studies from progressing. Currently, there is no strong evidence that shows causation between complete splenectomy and GDV development, so it is difficult to draw clinical conclusions as to if a concurrent prophylactic gastropexy during and / or soon after complete splenectomy is of benefit to the general population of canine patients.

\section{Methodology Section}

\begin{tabular}{|c|c|}
\hline \multicolumn{2}{|l|}{ Search Strategy } \\
\hline $\begin{array}{r}\text { Databases searched and dates } \\
\text { covered: }\end{array}$ & $\begin{array}{l}\text { PubMed on NCBI Platform; } 1984-2020 \\
\text { CAB Abstracts on OVID Platform; } 1973-2020\end{array}$ \\
\hline Search terms: & $\begin{array}{l}\text { PubMed and CAB Abstracts: } \\
\text { (dog OR canine) AND (GDV OR gastric dilatation OR gastric dilatation } \\
\text { volvulus OR gastropexy OR bloat) AND (splenectomy OR spleen) }\end{array}$ \\
\hline Dates searches performed: & 15 Jun 2021 \\
\hline
\end{tabular}




\begin{tabular}{|c|c|}
\hline Exclusion / Inclusion Criteria & \\
\hline Exclusion: & $\begin{array}{l}\text { - Book chapters. } \\
\text { - Clinical review articles. } \\
\text { - Articles not available in English. }\end{array}$ \\
\hline Inclusion: & $\begin{array}{l}\text { - Articles available in English which were relevant to the PICO } \\
\text { and involved more than one animal. }\end{array}$ \\
\hline
\end{tabular}

\begin{tabular}{|l|c|c|c|c|c|c|}
\hline \multicolumn{2}{|l|}{ Search Outcome } \\
\hline Database & $\begin{array}{r}\text { Number } \\
\text { of } \\
\text { results }\end{array}$ & $\begin{array}{c}\text { Excluded - } \\
\text { Review }\end{array}$ & $\begin{array}{c}\text { Excluded - Not } \\
\text { relevant }\end{array}$ & $\begin{array}{c}\text { Excluded - Full } \\
\text { article not } \\
\text { available }\end{array}$ & $\begin{array}{c}\text { Excluded - One } \\
\text { animal study }\end{array}$ & $\begin{array}{c}\text { Total } \\
\text { relevant } \\
\text { papers }\end{array}$ \\
\hline PubMed & 23 & 2 & 15 & 0 & 1 & 5 \\
\hline CAB & 36 & 2 & 29 & 0 & 3 & 2 \\
\hline Abstracts & 23 & & & 5 \\
\hline
\end{tabular}

\section{CONFLICT OF INTEREST}

The authors declare no conflict of interest.

\section{REFERENCES}

1. DeGroot, W., Giuffrida, M.A., Rubin, J., Runge, J.J., Zide, A., Mayhew, P.D., Culp, W.T.N., Mankin, K.T., Amsellem, P.M., Petrukovich, B., Ringwood, P.B., Case, J.B. \& Singh, A. (2016). Primary splenic torsion in dogs: 102 cases (1992-2014). Journal of the American Veterinary Medical Association. 248(6), 661668. DOI: https://doi.org/10.2460/iavma.248.6.661

2. Goldhammer, M.A., Haining, H., Milne, E.M., Shaw, D.J. \& Yool, D.A. (2010). Assessment of the incidence of GDV following splenectomy in dogs. Journal of Small Animal Practice. 51(1), 23-28. DOI: https://doi.org/10.1111/i.1748-5827.2009.00844.x

3. Grange, A.M., Clough, W. \& Casale, S.A. (2012). Evaluation of splenectomy as a risk factor for gastric dilatation-volvulus. Journal of the American Veterinary Medical Association. 241(4), 461-466. DOI: https://doi.org/10.2460/javma.241.4.461

4. Maki, L.C., Males, K.N., Byrnes, M.J., El-Saad, A.A. \& Coronado, G.S. (2017). Incidence of gastric dilatation-volvulus following a splenectomy in 238 dogs. The Canadian Veterinary Journal. 58(12): 1275-1280.

5. Sartor, A.J., Bentley, A.M. \& Brown, D.C. (2013). Association between previous splenectomy and gastric dilatation-volvulus in dogs: 453 cases (2004-2009). Journal of the American Veterinary Medical Association. 242(10), 1381-1384. DOI: https://doi.org/10.2460/javma.242.10.1381

6. Loy Son, N.K., Singh, A., Amsellem, P., Kilkenny, J., Brisson, B.A., Oblak, M.L. \& Ogilvie, A.T. (2016). Long-Term Outcome and Complications Following Prophylactic Laparoscopic-Assisted Gastropexy in Dogs. Veterinary Surgery. 45(S1), 77-83. DOI: https://doi.org/10.1111/vsu.12568 


\section{EVIIDEFeE

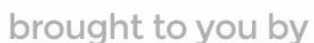 \\ RCVS KNOWLEDGE}

\section{Intellectual Property Rights}

Authors of Knowledge Summaries submitted to RCVS Knowledge for publication will retain copyright in their work, and will be required to grant RCVS Knowledge a non-exclusive license of the rights of copyright in the materials including but not limited to the right to publish, re-

publish, transmit, sell, distribute and otherwise use the materials in all languages and all media throughout the world, and to license or permit others to do so.

\section{Disclaimer}

Knowledge Summaries are a peer-reviewed article type which aims to answer a clinical question based on the best available current evidence. It does not override the responsibility

of the practitioner. Informed decisions should be made by considering such factors as individual clinical expertise and judgement along with patient's circumstances and owners' values. Knowledge Summaries are a resource to help inform and any opinions expressed within the Knowledge Summaries are the author's own and do not necessarily reflect the view of the RCVS Knowledge. Authors are responsible for the accuracy of the content. While the

Editor and Publisher believe that all content herein are in accord with current recommendations and practice at the time of publication, they accept no legal responsibility

for any errors or omissions, and make no warranty, express or implied, with respect to material contained within.

For further information please refer to our Terms of Use.

RCVS Knowledge is the independent charity associated with the Royal College of Veterinary Surgeons (RCVS). Our ambition is to become a global intermediary for evidence based veterinary knowledge by providing access to information

that is of immediate value to practicing veterinary professionals and directly contributes to evidence based clinical decision-making.

https://www.veterinaryevidence.org/

RCVS Knowledge is a registered Charity No. 230886.

Registered as a Company limited by guarantee in England and Wales No. 598443.

Registered Office: Belgravia House, 62-64 Horseferry Road, London SW1P 2AF

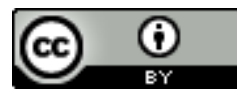

This work is licensed under a Creative Commons Attribution 4.0 International License 